\title{
A Specific and Sensitive Assay for Gefitinib Using the Enzyme-Linked Immunosorbent Assay in Human Serum
}

\author{
Tetsuya Saita, ${ }^{*}$ Hiroshi Fusito, and Masato Mori \\ Department of Pharmacy, Saga University Hospital; 5-1-1 Nabeshima, Saga 849-8501, Japan. \\ Received May 16, 2005; accepted July 4, 2005
}

\begin{abstract}
The epidermal growth factor tyrosine kinase inhibitor gefitinib is a novel, molecularly targeted agent that has been approved for the treatment of advanced non-small cell lung cancer. This paper reports a specific and sensitive enzyme-linked immunosorbent assay (ELISA) for pharmacokinetic studies of gefitinib. Anti-gefitinib antibody was obtained by immunizing rabbits with an antigen conjugated with bovine serum albumin using diazotized 4-amino-2-methoxy-1-[3-(morpholin-4-yl)propoxy]benzene. Enzyme labeling of gefitinib with $\beta$-D-galactosidase was similarly performed using a diazotized 4-amino-2-methoxy-1-[3-(morpholin-4-yl)propoxy]benzene. A simple ELISA for gefitinib was developed using the principle of direct competition between gefitinib and the enzyme marker for anti-gefitinib antibody which had been adsorbed to the plastic surface of a microtiter plate. Gefitinib concentrations in serum lower than $800 \mathrm{pg} / \mathrm{ml}$ were measurable reproducibly using the ELISA. Crossreactivity data showed that the antibody well recognizes both the 3-morpholinopropoxy and methoxy moieties well, and thus is sufficiently specific for the structure of gefitinib. Using this assay, drug levels were easily measured in the serum of rabbits after oral administration of gefitinib at a single dose of $5 \mathrm{mg} / \mathrm{kg}$. The specificity and sensitivity of the ELISA for gefitinib should provide a valuable new tool for use in pharmacokinetic and toxicity studies of gefitinib.
\end{abstract}

Key words gefitinib; enzyme-linked immunosorbent assay; anticancer drug

Gefitinib, N-(3-chloro-4-fluorophenyl)-7-methoxy-6-[3(morpholin-4-yl)propoxy] quinazolin-4-amine is an orally active epidermal growth factor receptor tyrosine kinase inhibitor (EGFR-TKI) that blocks signal transduction pathways implicated in cancer cell proliferation, survival, and host-dependent processes promoting cancer growth. ${ }^{1,2)}$ Gefitinib exhibits a broad spectrum of antitumor activity against many human solid tumor xenografts including breast, pancreas, lung, colorectal, and head and neck cancer. ${ }^{3,4)}$ Gefitinib is now approved for the treatment of advanced non-small cell lung cancer in several countries, including Australia, Japan, and the U.S.A. However, gefitinib has also been reported to produce interstitial lung disease in some patients. ${ }^{5,6)}$ Thus clinical evaluation of gefitinib is still controversial and further studies are needed.

In clinical trials, it was observed that there is no relationship between gefitinib blood concentration and antitumor activity. ${ }^{7)}$ However, dose dependency was revealed in the onset of skin and gastrointestinal toxicity, suggesting a relation with gefitinib blood concentration. ${ }^{7-9)}$ Moreover, there are 4- to 10-fold individual differences in gefitinib blood concentration in the steady state. ${ }^{7-9)}$ Therefore the gefitinib blood concentration must be monitored to minimize its side effects. Previous pharmacokinetic studies of gefitinib were undertaken with liquid chromatography-mass spectrometry/mass spectrometry (LC-MS/MS). ${ }^{10)}$ LC-MS/MS is a specific, accurate, and reproducible method. However, it requires expensive instrumentation and a high degree of technical expertise. Thus the development of a simple quantification method of gefitinib is needed. The enzyme-linked immunosorbent assay (ELISA) is generally very sensitive and specific and has advantages in simplicity, cost, safety, and ability to process numerous samples. If a kit and automatic method could be developed, it would be used in many facilities. We have already developed several ELISAs for some anticancer drugs, each of which was simple, sensitive, and useful for pharmacoki- netic studies of the individual drugs. ${ }^{11-13)}$

We present here the first report of an ELISA for gefitinib, including the methodology for antibody production, labeling of gefitinib with $\beta$-D-galactosidase $(\beta$-Gal) to act as a tracer, characterization of antibody specificity, and technique developed for the measurement of gefitinib with the ELISA. The initial application of the assay to the measurement of drug levels in rabbits demonstrates its usefulness for the assessment of basic pharmacokinetic distribution.

\section{MATERIALS AND METHODS}

Equipment The IR spectrum was recorded using a Hitachi 270-30 spectrometer (Hitachi, Tokyo, Japan). The proton nuclear magnetic resonance $\left({ }^{1} \mathrm{H}-\mathrm{NMR}\right)$ spectrum was recorded with a JEOL-MY60FT spectrometer (JEOL, Tokyo, Japan) at $60 \mathrm{MHz}$ using tetramethylsilane as an internal standard. Enzymatic activity was measured using a fluorescence microplate reader (Fluoroskan Ascent, Labsystems, Helsinki, Finland).

Reagents Gefitinib was supplied by AstraZeneca Pharmaceuticals (Macclesfield, U.K.) with a purity of 99\%. 4-(3Hydroxypropyl)morpholine and 4-nitroguaiacol were obtained from Aldrich Chemical Co. (St. Louis, MO, U.S.A.). Catechol was obtained from Wako Pure Chemical Industries (Osaka, Japan). $\beta$-D-Galactosidase ( $\beta$-Gal; EC 3.2.1.23) from Escherichia coli and 4-methylumbelliferyl- $\beta$-D-galactopyranoside were obtained from Boehringer Mannheim (Mannheim, Germany). All other reagents and solvents were of the highest grade commercially available.

2-[3-(Morpholin-4-yl)propoxy]phenol To a solution of 4-(3-hydroxypropyl)morpholine $(100 \mathrm{mg}, 0.7 \mathrm{mmol})$ in dry benzene $(10 \mathrm{ml}), \mathrm{SOCl}_{2}(0.15 \mathrm{ml})$ was added dropwise in an ice bath and the mixture was then heated at $40^{\circ} \mathrm{C}$ for $1 \mathrm{~h}$. After evaporation of the solvent, the residue was dissolved in toluene $(10 \mathrm{ml})$. The toluene solution was added to a solution 
of catechol ( $80 \mathrm{mg}, 0.7 \mathrm{mmol})$ in $2 \% \mathrm{~K}_{2} \mathrm{CO}_{3}(5 \mathrm{ml})$. The mixture was heated under reflux at $120^{\circ} \mathrm{C}$ for $8 \mathrm{~h}$. After cooling to room temperature, the toluene layer was dried over anhydrous $\mathrm{Na}_{2} \mathrm{SO}_{4}$, and reduced by evaporation. The residue was purified on a silica gel $60(70-230$ mesh) column chromatographed with $\mathrm{CHCl}_{3}-\mathrm{CH}_{3} \mathrm{OH}(20: 1, \mathrm{v} / \mathrm{v})$. A total of 95 $\mathrm{mg}(40 \%)$ of 2-[3-(morpholin-4-yl)propoxy]phenol (MPP) as a white powder was obtained: $\mathrm{mp} 102-103^{\circ} \mathrm{C}$. IR $(\mathrm{KBr})$ $\mathrm{cm}^{-1}:$ 2964, 1496, 1266, 1112. ${ }^{1} \mathrm{H}-\mathrm{NMR}\left(\mathrm{CDCl}_{3}\right) \delta: 1.97$ $\left(2 \mathrm{H}, \mathrm{t}, J=6.1 \mathrm{~Hz},-\mathrm{CH}_{2} \mathrm{CH}_{2} \mathrm{CH}_{2}-\right), 2.50-2.74(6 \mathrm{H}, \mathrm{m}, \mathrm{N}$ $\left.\left(\mathrm{CH}_{2}\right)_{3}\right), 3.74-4.09\left(6 \mathrm{H}, \mathrm{m}, \mathrm{O}\left(\mathrm{C}_{2}\right)_{3}\right), 6.86-6.99(4 \mathrm{H}, \mathrm{m}$, $\operatorname{Ar} \underline{\underline{H}})$.

3-Methoxy-4-[3-(morpholin-4-yl)propoxy]nitrobenzene To a solution of 4-(3-hydroxypropyl)morpholine (100 mg, $0.7 \mathrm{mmol})$ in dry benzene $(10 \mathrm{ml}), \mathrm{SOCl}_{2}(0.15 \mathrm{ml})$ was added dropwise in an ice bath and the mixture was then heated at $40^{\circ} \mathrm{C}$ for $1 \mathrm{~h}$. After evaporation of the solvent, the residue was dissolved in toluene $(10 \mathrm{ml})$. The toluene solution was added to a solution of 4-nitroguaiacol (100 mg, 0.6 $\mathrm{mmol})$ in $2 \% \mathrm{~K}_{2} \mathrm{CO}_{3}(5 \mathrm{ml})$. The mixture was heated under reflux at $120^{\circ} \mathrm{C}$ for $8 \mathrm{~h}$. After cooling to room temperature, the toluene layer was washed with saturated $\mathrm{NaCl}$, dried over anhydrous $\mathrm{Na}_{2} \mathrm{SO}_{4}$, and reduced by evaporation. The residue was purified on a silica gel $60(70-230$ mesh $)$ column chromatographed with $\mathrm{CHCl}_{3}-\mathrm{CH}_{3} \mathrm{OH}(20: 1, \mathrm{v} / \mathrm{v})$. A total of 80 $\mathrm{mg}(40 \%)$ of 3-methoxy-4-[3-(morpholin-4-yl)propoxy] nitrobenzene (MMNB) as a pale yellow oil was obtained. IR $\left(\mathrm{CCl}_{4}\right) \mathrm{cm}^{-1}: 2956,1512,1338,1274 .{ }^{1} \mathrm{H}-\mathrm{NMR}\left(\mathrm{CDCl}_{3}\right) \delta$ : $2.05\left(2 \mathrm{H}, \mathrm{t}, J=6.8 \mathrm{~Hz},-\mathrm{CH}_{2} \mathrm{CH}_{2} \mathrm{CH}_{2}-\right), 2.39-2.67[6 \mathrm{H}, \mathrm{m}$, $\left.\mathrm{N}\left(\mathrm{CH}_{2}\right)_{3}\right], 3.72\left[4 \mathrm{H}, \mathrm{t}, J=4.7 \mathrm{~Hz}, \mathrm{O}\left(\mathrm{CH}_{2}\right)_{2}\right], 3.95(3 \mathrm{H}, \mathrm{s}$, $\left.\mathrm{CH}_{3} \mathrm{O}\right), 4.2\left(2 \mathrm{H}, \mathrm{t}, J=6.4 \mathrm{~Hz}, \underline{\mathrm{CH}}_{2} \mathrm{OAr}\right), 6.87-7.81(3 \mathrm{H}$, $\mathrm{m}, \mathrm{Ar} \underline{\mathrm{H}})$.

Coupling Reaction for Hapten A solution of $10 \mathrm{mg}$ of MMNB was dissolved in $1 \mathrm{ml}$ of $60 \%$ ethanol and alkaline with $40 \mathrm{mg}$ of $\mathrm{MgO}$. To this mixture was added $80 \mathrm{mg}$ of $\mathrm{Na}_{2} \mathrm{~S}_{2} \mathrm{O}_{3}$ which was vigorously shaken, and the solution was heated in a water bath at $50^{\circ} \mathrm{C}$ for $2 \mathrm{~h}$. After cooling, ethanol was distilled by evaporation in vacuo, and the aqueous solution was washed with AcOEt to remove unreacted MMNB. The aqueous layer was evaporated, and the residue was dissolved in ethanol. The resulting suspension was filtered and the filtrate evaporated in vacuo to give 4-amino2-methoxy-[3-(morpholin-4-yl)propoxy]benzene (AMMB) $(5 \mathrm{mg}, 50 \%)$ as a yellow solid. The resulting AMMB was conjugated with bovine serum albumin (BSA) and $\beta$-Gal, respectively, as a gefitinib immunogen and a tracer.

AMMB (approximately $5 \mathrm{mg}, 20 \mu \mathrm{mol}$ ) in $20 \mu \mathrm{l}$ dimethylformamide was acidified by the addition of $100 \mu \mathrm{l}$ of $1 \mathrm{M}$ acetic acid and then diazotized with sodium nitrite $(2.8 \mathrm{mg}$, $40.5 \mu \mathrm{mol})$ in $50 \mu \mathrm{l}$ of distilled water at $0^{\circ} \mathrm{C}$ for $10 \mathrm{~min}$. The solution was immediately mixed with BSA $(10 \mathrm{mg})$ in $1 \mathrm{ml}$ of $0.5 \mathrm{M}$ borate buffer ( $\mathrm{pH} 9.5$ ), followed by 1 -h incubation at room temperature. The mixture was chromatographed on a Sephadex G-100 column $(2.8 \times 42 \mathrm{~cm})$ with $0.1 \mathrm{~m}$ phosphate buffer ( $\mathrm{pH}$ 7.0) containing $3 \mathrm{~m}$ urea. The degree of coupling of diazotized AMMB with BSA was determined based on amino acid analysis after hydrolysis with $6 \mathrm{M} \mathrm{HCl}$ at $110^{\circ} \mathrm{C}$ for $24 \mathrm{~h}^{14)}$ Seven moles of the hapten were found to be coupled with one mole of BSA on the basis of the decrease in moles of histidine and tyrosine. The amount of protein was determined using Lowry et al.'s method. ${ }^{15)}$
Preparation of Gefitinib Antibody An aliquot of a solution containing $1 \mathrm{mg}$ of AMMB-BSA conjugate $(1.5 \mathrm{ml})$ was emulsified with an equal volume of Freund's complete adjuvant. Two white female rabbits were administered multiple subcutaneous injections of the solution at sites along both sides of their backs. Booster injections were then administered three times at biweekly intervals, using one-half the amount of the dose of the first immunization. The rabbits were bled from an ear vein 10 weeks after immunization began. The sera $(10 \mathrm{ml})$ were separated by centrifugation and heated at $55^{\circ} \mathrm{C}$ for $30 \mathrm{~min}$. Fractions of $\mathrm{IgG}$ were extracted from the sera with $50 \%$ saturated ammonium sulfate and chromatographed on a column of DEAE-Sephacel $(2.1 \times 23 \mathrm{~cm})$ using $17.5 \mathrm{~mm}$ phosphate buffer $(\mathrm{pH} 6.8)$ as an eluent. The fraction passed through the column was lyophilized and used as anti-gefitinib IgG for ELISA.

Preparation of the Gefitinib- $\boldsymbol{\beta}$-Gal Conjugate Gefitinib was labeled by binding to $\beta$-Gal, essentially by the same method as used for the preparation of gefitinib immunogen. AMMB (approximately $6 \mathrm{mg}, 24 \mu \mathrm{mol}$ ) in DMF $20 \mu \mathrm{l}$ was acidified by the addition of $100 \mu \mathrm{l}$ of $1 \mathrm{M}$ acetic acid and then diazotized with sodium nitrite $(3.3 \mathrm{mg}$, $48 \mu \mathrm{mol}$ ) in $100 \mu \mathrm{l}$ of distilled water at $0^{\circ} \mathrm{C}$ for $10 \mathrm{~min}$. Next, a $30-\mu 1$ aliquot of the above reaction mixture containing diazotized AMMB (ca. $3.3 \mu \mathrm{mol}$ ) was added directly to $\beta$-Gal $(156 \mu \mathrm{g}, 0.28 \mathrm{nmol})$ in $0.5 \mathrm{ml}$ of $0.5 \mathrm{M}$ phosphate buffer $(\mathrm{pH}$ $7.5)$, followed by $1-\mathrm{h}$ incubation at room temperature. The mixture was chromatographed on a column of Sepharose $6 \mathrm{~B}$ $(2.0 \times 40 \mathrm{~cm})$ using $20 \mathrm{~mm}$ phosphate buffer $(\mathrm{pH} 7.0)$ containing $0.1 \mathrm{M} \mathrm{NaCl}, 1 \mathrm{mM} \mathrm{MgCl}_{2}, 0.1 \% \mathrm{BSA}$, and $0.1 \% \mathrm{NaN}_{3}$ (buffer A) to remove the remaining small molecules. Fourmilliliter fractions were collected, and fractions 15 to 17, representing the main peaks showing enzyme activity, were combined and used as a label in the ELISA.

ELISA for Gefitinib ELISA is based on the principle of competition between enzyme-labeled and unlabeled drugs for an immobilized antibody, followed by measurement of the marker enzyme activity of the immunocomplex bound to the solid phase. Briefly, the wells in microtiter plates (Nunc F Immunoplates I; Nunc, Reskilde, Denmark) were coated by loading $150 \mu \mathrm{l}$ of anti-gefitinib $\operatorname{IgG}(1.0 \mu \mathrm{g} / \mathrm{ml})$ in $10 \mathrm{~mm}$ Tris- $\mathrm{HCl}$ buffer (pH 8.5) containing $10 \mathrm{~mm} \mathrm{NaCl}$ and $10 \mathrm{~mm}$ $\mathrm{NaN}_{3}$ and allowed to stand for $1 \mathrm{~h}$ at $37^{\circ} \mathrm{C}$. After the plates had been washed twice with $60 \mathrm{~mm}$ phosphate buffer $(\mathrm{pH}$ 7.4) containing $10 \mathrm{~mm}$ ethylenediaminetetraacetate, $0.1 \%$ BSA and $0.1 \% \mathrm{NaN}_{3}$ (buffer B), they were incubated with $200 \mu \mathrm{l}$ of $10 \mathrm{~mm}$ Tris- $\mathrm{HCl}$ buffer $(\mathrm{pH} 8.5)$ containing $10 \mathrm{~mm}$ $\mathrm{NaCl}$ and $10 \mathrm{~mm} \mathrm{NaN}_{3}$ containing 2\% BSA for $20 \mathrm{~min}$ at $37^{\circ} \mathrm{C}$ to prevent nonspecific adsorption. The anti-gefitinib IgG-coated wells were then filled with $50 \mu \mathrm{l}$ of either gefitinib-treated samples, or buffer B as a control, followed immediately by $50 \mu \mathrm{l}$ of the pooled gefitinib- $\beta$-Gal conjugate (diluted 1:300 in buffer B for gefitinib). The wells were then incubated overnight at room temperature and once again washed thoroughly with buffer B.

The activity of the enzyme conjugate bound to each well was then measured by the addition of $125 \mu \mathrm{l}$ of $0.1 \mathrm{~mm}$ methylumbelliferyl- $\beta$-D-galactopyranoside in buffer $\mathrm{A}$, followed by incubation of the wells at $37^{\circ} \mathrm{C}$ for $60 \mathrm{~min}$. The enzyme reaction was stopped by the addition of $75 \mu \mathrm{l}$ of $0.5 \mathrm{M}$ glycine- $\mathrm{NaOH}$ buffer ( $\mathrm{pH} 10.3$ ) to each well, and the result- 
ing 4-methylumbelliferone concentration was determined by spectrofluorometry at wavelengths of $355 \mathrm{~nm}$ for excitation and $460 \mathrm{~nm}$ for emission using a fluorescence microplate reader. Concentrations were calculated from the standard curve using semilogarithmic graph paper.

Pharmacokinetic Evaluation Three white female rabbits in the weight range of 3.5 to $4.0 \mathrm{~kg}$ were used in this study. Gefitinib was orally administered at a dose of $5 \mathrm{mg} / \mathrm{kg}$ to the rabbits. The drug was suspended in a carrier composed of $10 \%$ DMSO and isotonic sodium chloride at concentrations of $5 \mathrm{mg} / \mathrm{ml}$. Blood samples were collected at $0.5,1,2$, $3,4,5,6,8$, and $24 \mathrm{~h}$ postadministration, and the serum was stored at $-30^{\circ} \mathrm{C}$ until the assay of gefitinib concentration. The serum was diluted 40 -fold with buffer B to obtain a gefitinib concentration appropriate for measurement using ELISA.

\section{RESULTS AND DISCUSSION}

The major metabolite of gefitinib in humans is $O$ desmethylgefitinib (Fig. 1). During long-term therapy, the plasma level of $O$-desmethylgefitinib is comparable with that of gefitinib. Therefore, to develop an ELISA for gefitinib which can be applied to the pharmacokinetic studies of gefitinib, it is necessary to produce an anti-gefitinib antibody that does not show a cross-reaction with the major metabolite $O$ desmethylgefitinib. In general, the antibody specificity on hapten appears to be toward the group farthest away from the region of conjugation to the carrier protein in the immunogen structure. ${ }^{16,17)}$ Thus, to produce an antibody specific for both the 3-morpholinopropoxy and the methoxy moieties of gefitinib, gefitinib immunogen was prepared using a partial structure of gefitinib (AMMB) (Fig. 2). The $\mathrm{AMMB}$ was coupled by diazotization to tyrosine and histidine residues on the carrier protein. The AMMB-BSA conjugate, with $7.0 \mathrm{~mol}$ of $\mathrm{AMMB}$ per mol of BSA, induced the formation of specific antibodies in each of two the rabbits immunized. AMMB- $\beta$-Gal conjugate was also prepared following essentially the same procedure. The conjugate thus obtained was stable for more than 6 months in eluted buffer (pH 7.0) at $4{ }^{\circ} \mathrm{C}$ without any loss of the enzyme and immunoreactive enzyme activity.

Using anti-gefitinib antibody and gefitinib- $\beta$-Gal as a tracer, an ELISA for the quantification of gefitinib was developed. The dose-response standard curve of gefitinib obtained in the human serum is shown in Fig. 3. The curve was essentially linear on a semilogarithmic plot between 0.8 and $100 \mathrm{ng} / \mathrm{ml}$. For practical purposes, the working range was arbitrarily set between 0.8 and $100 \mathrm{ng} / \mathrm{ml}$ based on the precision and accuracy findings for the ELISA in serum (Table 1), which showed this ELISA to be a reproducible technique. Recoveries of four different gefitinib levels ranging from 0.8 to $100 \mathrm{ng} / \mathrm{ml}$ were satisfactory $(98.8$ to $107.5 \%, n=5)$. The coefficients of variation for intra- and interassays at four different gefitinib levels between 0.8 to $100 \mathrm{ng} / \mathrm{ml}$ was 6.3 to $9.5 \%$ and 5.1 to $9.0 \%$ (each $n=5$ ), respectively. The detection limit of gefitinib in the ELISA was $800 \mathrm{pg} / \mathrm{ml}$ (Student's $t$-test, $n=3, p<0.001$ compared with the $\mathrm{B}_{0}$ value). The plasma concentration range in the usual clinical dose of gefitinib is between about 10 and $200 \mathrm{ng} / \mathrm{ml}$ (data on file at AstraZeneca). Therefore this ELISA may be sufficiently sensi-

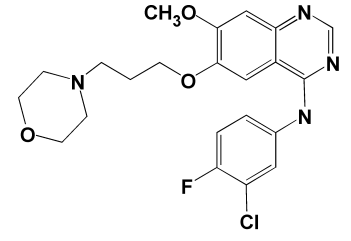

Gefitinib

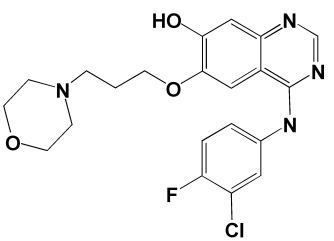

$O$-Desmethylgefitinib
Fig. 1. Chemical Structures of Gefitinib and Its Major Metabolite

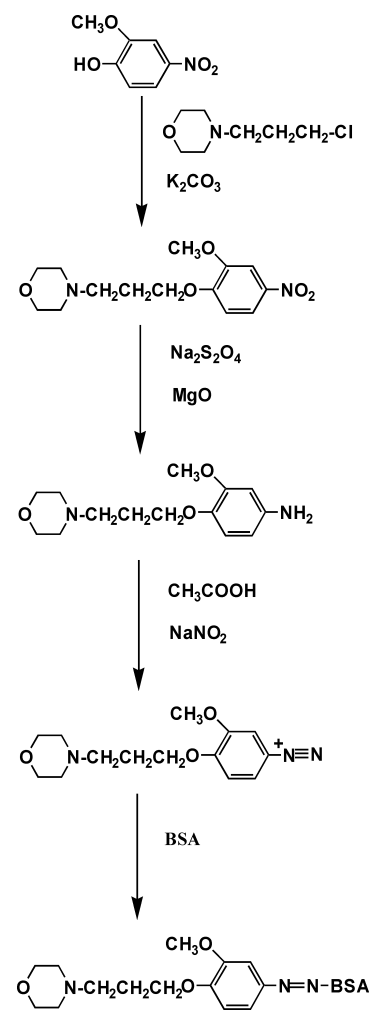

Fig. 2. Preparation of the Immunogen for Gefitinib

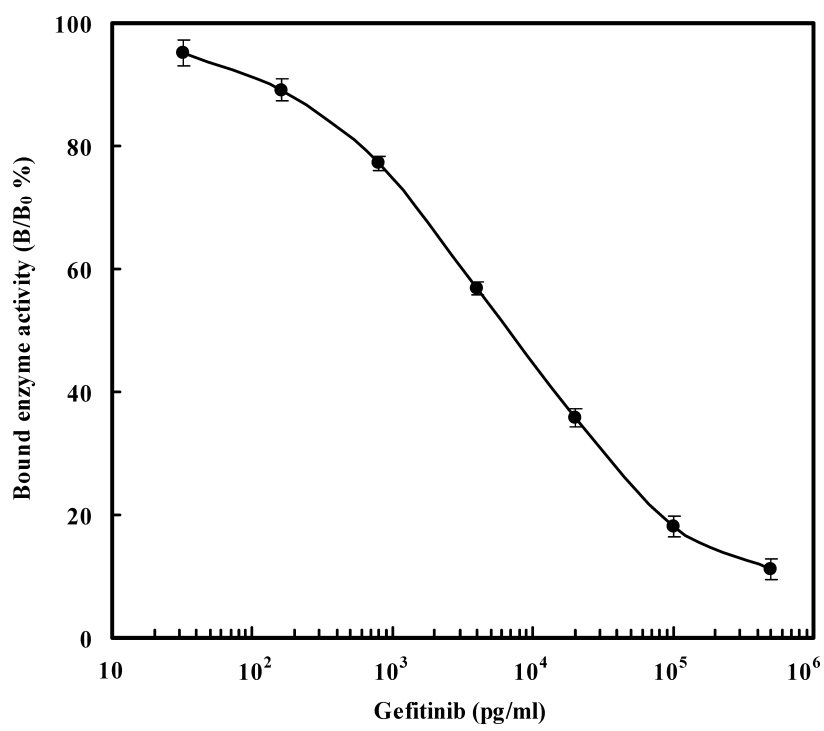

Fig. 3. Standard Curve for Gefitinib in Human Serum

The curve shows the amount (\%) of bound enzyme activity for various doses of gefitinib (B) as a ratio of that bound using gefitinib- $\beta$-Gal alone $\left(\mathrm{B}_{0}\right)$. Each point represents the mean \pm S.D. of 5 replicates. 
Table 1. Precision and Recovery of ELISA for Gefitinib in Human Serum

\begin{tabular}{lcccc}
\hline \hline & Added $(\mathrm{ng} / \mathrm{ml})$ & Estimated $(\mathrm{ng} / \mathrm{ml})$ & Recovery $(\%)$ & C.V. $(\%)$ \\
\hline Intraassay & 0.8 & $0.86 \pm 0.06$ & 107.5 & 7.0 \\
& 4.0 & $4.14 \pm 0.3$ & 103.5 & 7.2 \\
& 20.0 & $20.8 \pm 1.3$ & 104.0 & 6.3 \\
Interassay & 100.0 & $104.8 \pm 10$ & 104.8 & 9.5 \\
& 0.8 & $0.81 \pm 0.07$ & 101.3 & 8.6 \\
& 4.0 & $3.95 \pm 0.2$ & 98.8 & 5.1 \\
& 20.0 & $19.9 \pm 1.7$ & 99.5 & 8.5 \\
& 100.0 & $100.8 \pm 9.1$ & 100.8 & 9.0 \\
\hline
\end{tabular}

Values represent the mean \pm S.D. of 5 experiments.

Table 2. Specificity of Anti-gefitinib IgG

4-(3-Hydroxypropyl)morpholine

tive to quantify gefitinib in pharmacokinetic studies.

An antibody specificity was determined based on the displacement of bound gefitinib- $\beta$-Gal by similar compounds. Values of the cross-reactivity were defined as the ratio of each compound to gefitinib in the concentrations required for $50 \%$ inhibition of gefitinib- $\beta$-Gal binding to the antibody. The anti-gefitinib antibody showed $100.0 \%$ cross-reactivity with MMNB used as a hapten antigen, $3.8 \%$ with MPP, and $0.18 \%$ with 4-(3-hydroxypropyl)morpholine. No detectable cross-reaction, however, was found with 4-nitroguaiacol (Table 2). These findings suggest that the antibody well recognizes both the 3-morpholinopropoxy and methoxy moieties of gefitinib well, and thus is sufficiently specific for the structure of gefitinib.

As a demonstration of the potential of the ELISA, gefitinib was orally administered at a dose of $5 \mathrm{mg} / \mathrm{kg}$ to the rabbits, and serum concentration kinetics were monitored (Fig. 4). Gefitinib was rapidly absorbed, reached a peak concentration in the serum of $926.7 \pm 174.7 \mathrm{ng} / \mathrm{ml}$ (mean \pm S.D.) at $60 \mathrm{~min}$ after dosing, and then slowly decreased. The ELISA determinations, however, may quantify the total amounts of gefitinib immunoreactivity including gefitinib metabolites with crossreactivity with anti-gefitinib antibody. Five metabolites of gefitinib have already been identified in human plasma (data on file at AstraZeneca). The cross-reactivity of these metabolites has not yet been confirmed. However, it is estimated that the $O$-desmethylgefitinib, the major metabolite, shows a similar cross-reaction to MPP judging from the specificity of the

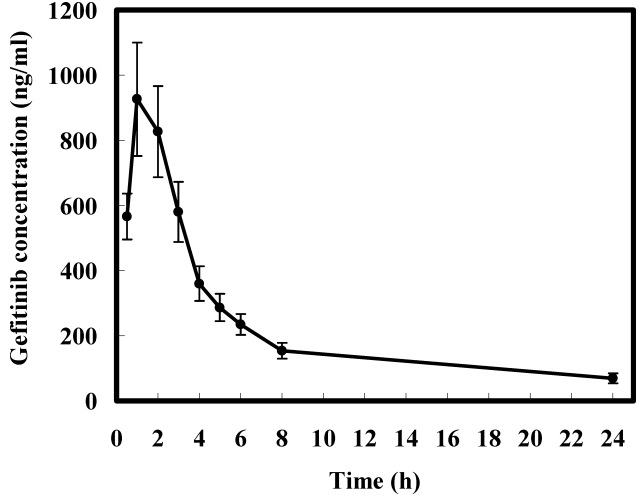

Fig. 4. Serum Gefitinib Levels in Rabbits after a Single Oral Administration of Gefitinib

Three rabbits, each weighing 3.5 to $4.0 \mathrm{~kg}$, were injected with $5 \mathrm{mg} / \mathrm{kg}$ gefitinib. At each interval, blood was collected and the serum gefitinib level was measured by ELISA. Each point represents the mean \pm S.D. of three rabbits.

anti-gefitinib antibody. In addition, the other three morpholin open-ring metabolites of gefitinib would not show the crossreaction. On the other hand, another metabolite (desfluorogefitinib) would show a cross-reaction similar to that of gefitinib. However, the maximal concentration of this metabolite detected in human plasma was relatively low (data on file at AstraZeneca). Therefore this ELISA may be sufficiently specific to quantify gefitinib for pharmacokinetic studies in humans.

In conclusion, the ELISA procedure for gefitinib reported here is sensitive, specific, reproducible, simple, and adaptable for the analyses of numerous samples. This ELISA will be a valuable tool in pharmacokinetic and toxicity studies of gefitinib.

Acknowledgment This study was supported in part by a Grant-in-Aid for Scientific Research (No. 16922068) from the Japan Society for the Promotion of Science.

\section{REFERENCES}

1) Wakeling A. E., Barker A. J., Davies D. H., Brown D. S., Green L. R., Cartlidge S. A., Woodburn J. R., Breast Cancer Res. Treat., 38, 6773 (1996)

2) Woodburn J. R., Barker A. J., Gibson K. H., Ashton S. E., Wakeling A. E., Curry B. J., Scarlett L., Henthorn L. R., Proc. Am. Assoc. Cancer Res., 38, 633 (1997).

3) Ciardiello F., Caputo R., Bianco R., Damiano V., Pomatico G., De Placido S., Bianco A. R., Tortora G., Clin. Cancer Res., 6, 20532063 (2000).

4) Wakeling A. E., Guy S. P., Woodburn J. R., Ashton S. E., Curry B. J., Barker A. J., Gibson K. H., Cancer Res., 62, 5749—5754 (2002).

5) Cohen M. H., Williams G. A., Sridhara R., Chen G., McGuinn W. D., Morse D., Abraham S., Rahman A., Liang C., Lostritto R., Baird A., Pazdur R., Clin. Cancer Res., 10, 1212-1218 (2004).

6) Inomata S., Takahashi H., Nagata M., Yamada G., Shiratori M., Tanaka H., Satoh M., Saitoh T., Sato T., Abe S., Anticancer Drugs, 15, 461-467 (2004)

7) Baselga J., Rischin D., Ranson M., Calvert H., Raymond E., Kieback D. G., Kaye S. B., Gianni L., Harris A., Bjork T., Averbuch S. D., Feyereislova A., Swaisland H., Rojo F., Albanell J., J. Clin. Oncol., 20, 4292-4302 (2002).

8) Herbst R. S., Maddox A. M., Rothenberg M. L., Small E. J., Rubin E. H., Baselga J., Rojo F., Hong W. K., Swaisland H., Averbuch S. D., Ochs J., LoRusso P. M., J. Clin. Oncol., 20, 3815-3825 (2002).

9) Ranson M., Hammond L. A., Ferry D., Kris M., Tullo A., Murray P. I., Miller V., Averbuch S., Ochs J., Morris C., Feyereislova A., Swaisland H., Rowinsky E. K., J. Clin. Oncol., 20, 2240-2250 (2002). 
10) Jones H. K., Stafford L. E., Swaisland H. C., Payne R., J. Pharm. Biomed. Anal., 29, 221-228 (2002).

11) Saita T., Fujiwara K., Kitagawa T., Mori M., Takata K., Cancer Chemother. Pharmacol., 27, 115-120 (1990).

12) Saita T., Fujito H., Mori M., Biol. Pharm. Bull., 23, $911-916$ (2000).

13) Saita T., Fujito H., Mori M., Biol. Pharm. Bull., 24, 321-326 (2001).

14) Chang J. Y., Knecht R., Braun D. G., Biochem. J., 203, 803-806
(1982).

15) Lowry O. H., Rosebrough N. J., Farr A. L., Randall R. J., J. Biol. Chem., 193, 265-275 (1951).

16) Van Weeman B. K., Schuurs A. H., Immunochemistry, 12, 667-670 (1975).

17) Fujiwara K., Saikusa H., Yasuno M., Kitagawa T., Cancer Res., 42, 1487-1491 (1982). 